SVERIGES RIKSBANK

WORKING PAPER SERIES

204

The Use of Cash and the Size of the Shadow Economy in Sweden

Gabriela Guibourg and Björn Segendorf 
WORKING PAPERS ARE OBTAINABLE FROM

Sveriges Riksbank • Information Riksbank • SE-103 37 Stockholm Fax international: +4687870526

Telephone international: +4687870100

E-mail: info@riksbank.se

The Working Paper series presents reports on matters in the sphere of activities of the Riksbank that are considered to be of interest to a wider public.

The papers are to be regarded as reports on ongoing studies and the authors will be pleased to receive comments.

The views expressed in Working Papers are solely the responsibility of the authors and should not to be interpreted as reflecting the views of the Executive Board of Sveriges Riksbank. 


\title{
The Use of Cash and the Size of the Shadow Economy in Sweden ${ }^{\dagger}$
}

\author{
Gabriela Guibourg * and Björn Segendorf** \\ Sveriges Riksbank Working Paper Series \\ No. 204 \\ March 2007
}

\begin{abstract}
We use an "unexplained demand for cash" approach to measure the size of the shadow economy in Sweden. The size of the shadow economy is found to have increased from 3.8 to 6.5 per cent of GDP from 1990 to 2004. This result is also supported by our finding of an increased residual between households' recorded disposable income and their consumption, investments and changes in net financial positions. Moreover, the correlation between the demand for cash that cannot be explained by recorded transactions and this residual is strong.
\end{abstract}

Keywords: Cash use; demand for cash, shadow economy, National Accounts, Financial Accounts

JEL classifications: E41; E26; H26

\footnotetext{
+ We are grateful to Tor Jacobson, Mikael Carlsson, Paolo Giordani, Jonas Niemeyer, Kerstin Mitlid and Mats Bergman for valuable suggestions and comments. We would also like to thank Statistics Sweden for help with providing and interpreting data.

The views expressed in this working paper are solely the responsibility of the authors and should not be interpreted as reflecting the view of the Executive Board of Sveriges Riksbank.

* Research Department, Sveriges Riksbank SE-103 37 Stockholm, Sweden. E-mail: gabriela.guibourg@riksbank.se.

**International Secretariat, Sveriges Riksbank SE-103 37 Stockholm, Sweden, E-mail:bjorn.segendorff@riksbank.se.
} 


\section{Introduction}

The shadow economy comprises non-recorded economic activity of which surprisingly little is known. ${ }^{1}$ All of these types of economic activities are not intrinsically bad; a considerable share of them accounts for transactions that would otherwise not have taken place in the formal economy. In this sense, they add to the total value of goods and services produced in the economy On the other hand, an increasing share of the shadow economy of total GDP may reflect the fact that citizens' law and rule abiding principles, as well as their support for the welfare state, are being undermined. For these reasons, it is important to better understand the shadow economy. ${ }^{2}$ The purpose of this study is to estimate the size of the shadow economy in Sweden and how it has developed from 1990 to 2004.

The method we use builds on the fact that cash is a payment instrument that is difficult to trace and that this property makes it an attractive means of payment in the shadow economy. Hence, if the share of the currency in circulation that is used in the shadow economy could be estimated, this could be used as a starting point to estimate the size of the shadow economy itself. The way this is done is by reducing the total demand for cash by the demand that can be explained by recorded transactions including the value of cash held by banks, merchants, users and public authorities. The part of the demand for cash that cannot be explained is then assumed to derive from activities in the shadow economy. Multiplying this unexplained demand by the assumed velocity of cash in the shadow economy gives the shadow-economy turnover. The total currency in circulation is measured as $M O$ and we find that the unexplained demand for cash has increased from 31 per cent to 58 per cent of MO over the period $1990-2004 .{ }^{3}$ Multiplying the unexplained demand for cash by the ratio GDP/M1, which is a standard estimate of the velocity of cash in the shadow economy, we find that the shadow economy almost doubled its share of GDP over the studied period. More precisely, it has increased from 3.8 per cent of GDP to 6.5 per cent. Its average size was 5.7 per cent of GDP. However, the results are sensitive to the estimated velocity of cash in the shadow economy. To corroborate our finding of a growing shadow economy, we compare households' annual disposable income including loans with households' annual consumption, investments and savings. Any residual between the income and the expenditure sides captures part of the transactions in the shadow economy, mostly the net flows of unrecorded savings and income in and out of the country. This does not allow us to estimate the size of the shadow economy, however. But since the residual is most likely a function of the turnover in the shadow economy, we can confirm the trend of a

\footnotetext{
${ }^{1}$ The shadow economy comprises barter transactions and other non-recorded legal transactions as well as criminal activities including tax evasion. For taxonomy of types of underground economic activities, see Schneider and Enste (2000).

${ }^{2}$ Alm and Torgler (2006) show the importance of social norms for tax morale in country comparisons between the U.S. and 14 European countries,(see Alm and Torgler 2006). It turns out that the U.S. has the highest tax morale and the smallest shadow economy, while Belgium and Portugal have the lowest tax morale and the largest shadow economies. Sweden and Spain both have relatively large shadow economies but also a relatively high tax morale. For this comparison, Alm and Torgler use estimates from a working paper by Scheider and Klinglmair.

${ }^{3} \mathrm{MO}$ is calculated as the total stock of banknotes and coins in circulation each year minus the Swedish monetary financial institutions' cash balances in Swedish kronor. In absolute terms, MO increased from SEK 55 billion in 1990 to SEK 94 billion in 2004
} 
growing shadow economy. More precisely, we find there to be a strong positive correlation between the residual and the unexplained demand for cash.

In a recently published study (2006), the Swedish Tax Agency estimates the value of undeclared earnings to SEK 115 - 120 billion. Our own estimates for $1998-2004$ give an average of SEK 151 billion. The difference may be explained by the fact that our estimates include all kinds of nonregistered transactions including narcotics trade, prostitution etc. According to the Swedish Tax Agency, undeclared earnings were more widespread in small-sized companies and among skilled workers than in other groups in the economy. Engström and Holmlund (2006) study income and expenditure data and estimate that Swedish households with at least one self-employed member underreport their income by at least 30 percent. This result is consistent with other revision methods used by the Swedish Tax Agency.

Our study is not the first to estimate the demand for cash and the size of the shadow economy. Humphrey et al. (2000) study Norwegian data and find that the size of the shadow economy is approximately 10 percent of GDP in 1999. Schneider and Enste (2000) review the currency demand and other methods and present estimates in 76 developing, transition, and OECD countries. Like our estimates, the estimates obtained by Schneider and Enste (2000) show an increase in the size of the shadow economy in Sweden over time. Their estimates are larger, however. Schneider (1994 and 2005) gives estimates ranging from 15.8 percent of GDP in 1989/90 to 18.7 percent in 2002/2003 with a peak of 19.9 percent in 1997/1998. ${ }^{4}$ The difference in the results between our study and that of Schneider and Enste is due to our different approaches to estimate the currency demand.

Schneider and Enste use an econometric method that estimates the demand for cash as a function of macro-economic variables such as average tax rate, the saving-deposit interest rate, per-capita income etc. while our more direct approach builds on point-of-sale transaction data.

The structure of this paper is as follows. First, we describe the method for estimating the demand for cash and then we apply it to the Swedish data. This is done in Section 2. In Section 3, we estimate the shadow economy through the use of the unexplained cash demand and evaluate the qualitative results by use of household data and, finally, Section 4 concludes.

\section{The Demand for Cash}

We describe the method in Section 2.1 and apply it to Swedish data in Section 2.2. In Section 2.3, we discuss and refine our estimate of the unexplained demand for cash.

\footnotetext{
${ }^{4}$ With a slightly different approach for the computation of the data series Johnson, Kaufman and Zoida-Lobotón (1998a, 1998b) obtain estimates for the Swedish shadow economy of 10.6 per cent of GDP.
} 


\subsection{Method}

The method we use follows Humphrey et al (2000). We start by estimating the use of cash in registered transactions at the point of sale (POS), where buyers and sellers meet directly. In this type of transactions, cash, cards, and checks can be used interchangeably. Data on POS turnover card and check payments is of high quality while there is no reliable data on cash payments. The value of cash payments is therefore estimated as the difference between total turnover from POS transactions and the value of card- and check payments. The value of cash payments in POS transactions is a flow variable, however. In order to estimate the stock of cash needed to sustain the estimated value of cash payments in registered transactions, we must divide the value of cash payments with an appropriate velocity for cash. This measure captures the velocity of cash in recorded POS transactions. Here, we compute the velocity as the average number of cash withdrawals per adult Swede and year. ${ }^{5}$ Our data only covers an ATM withdrawal which means that we underestimate the number of withdrawals and thus also the velocity of cash and that we overestimate the stock of cash needed.

Cash is also used for other legal purposes than registered POS transactions. It is held by financial institutions, merchants and the public sector to meet customers' demand for cash, it is held by individuals to meet liquidity needs, and it is used for non-recorded transactions between individuals, e.g. in the second-hand market.

The estimated total cash requirement is thus the sum of the cash held by private and public sectors and the cash required for registered sales. The difference between the actual demand for cash as measured by $\mathrm{MO}$ and the estimate is the unexplained demand for cash, most of which is likely to be used in the shadow economy.

\subsection{The Explained Demand for Cash in Sweden}

Data on POS transactions was obtained from the part of the national accounts that contains statistics on households' annual consumption expenditure by purpose. By deducting from total household consumption those expenditures that are most likely to be paid for with credit transfers or direct debits, we get the annual consumption expenditures that are likely to have been paid for at the point of sale. These expenditures cover retail purchases, hotels, restaurants, purchases of communications and transport services etc. ${ }^{6}$ In Section 2.3, we refine the calculations by including the estimated turnover in the second-hand market.

\footnotetext{
${ }^{5}$ Individuals may withdraw cash through the ATM terminals, through bank and post branches and through cash back services at certain chains of grocery stores. Adult individuals are defined as older than 14. The computation of the velocity of cash followed the methodology of Humphrey et al. (2000).

${ }^{6}$ The expenditure purposes chosen and their statistical codes are: 01 food and non-alcoholic beverages, 02 alcoholic beverages and tobacco, 03 clothing and footwear, 043 materials and services for the maintenance and repair of dwellings, 0454 solid fuels, coal, coke, briquettes, firewood, charcoal, peat and the like, 05 furnishings, household equipment and routine household maintenance, 06 health, 0713 bicycles, 072 operation costs of personal transport equipment, 073 transport services, 0811 postal services, 0812
} 
The Riksbank collects annual data on the value and number of card- and check payments as well as other non-cash payments. ${ }^{7}$ Data on cash holdings by financial institutions and the public sector is published by Statistics Sweden. ${ }^{8}$ Cash holdings by non-financial firms had to be estimated. ${ }^{9}$

The value of cash-based POS transactions is estimated by deducting the value of card- and check payments from the POS turnover. We show that the share of cash payments of the total turnover has decreased by 34 percentage units from 71 percent to 33 percent between 1990 and 2004 (see Figure 1). For the level of POS cash payments, see Table 1. Most of the decrease can be explained by the cash payments being replaced by card payments. Card payments have also replaced checks, the use of which fell sharply during the first part of the studied period and virtually disappeared at the end of the period. Two thirds of the fall in cash payments occurred between 1999 and 2004; a period characterised by a very rapid growth of card payments. During these years, the share of card payments of the total number of non-cash payments increased from 34 to 63 per cent

Figure 1. The use of cash, cards and checks at the point of sale measured each instrument's share of total value of point-of-sale transactions.

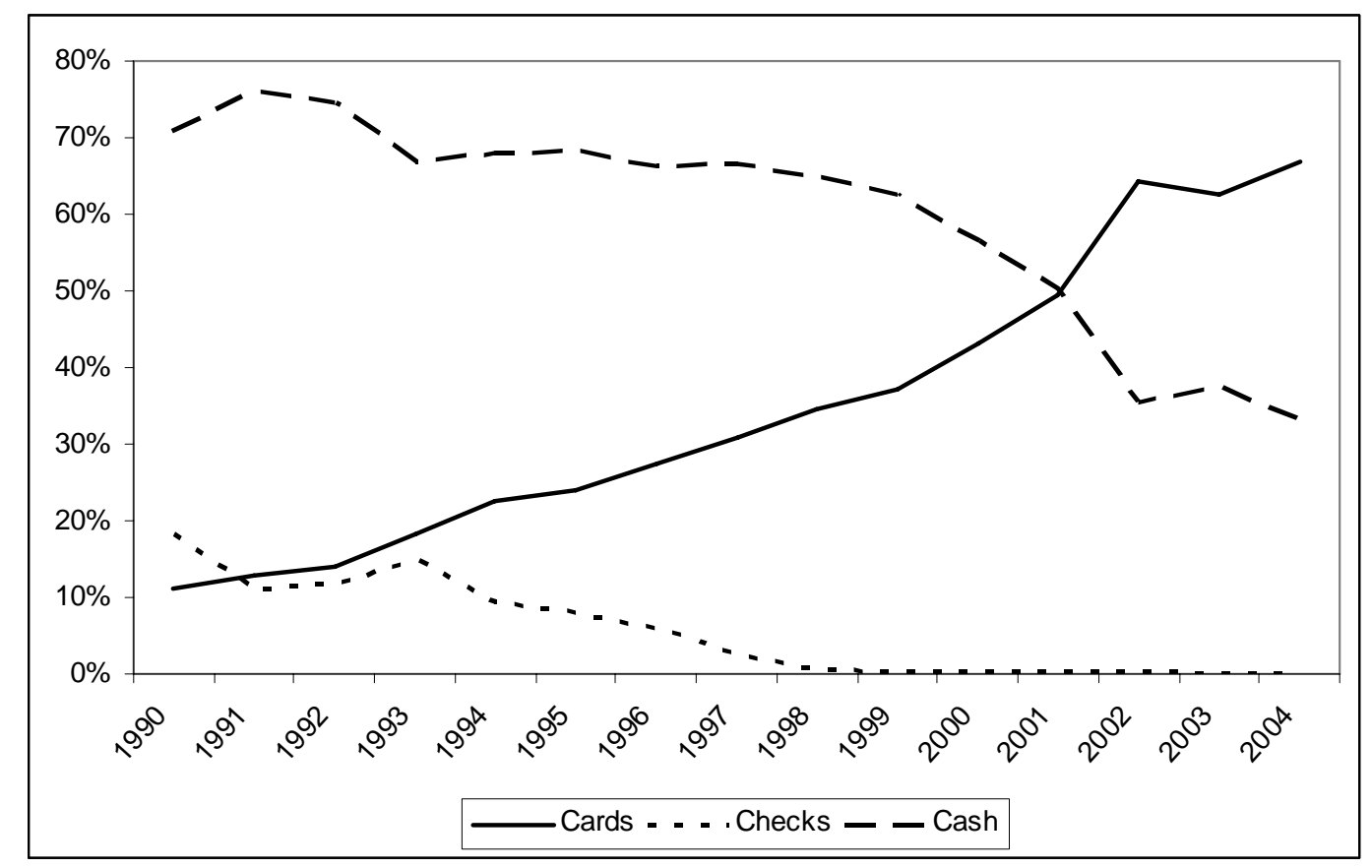

The value of cash payments for the years 2000 - 2004 can be found in Table 1. In order to obtain the stock of cash needed in registered trade, we divide the value of cash payments in registered sales with the velocity for cash in recorded POS transactions To this, we add the other cash holdings

telephone and telefax equipment, 09 recreation and culture, 10 education, 11 restaurants and hotels, 121 personal care, 123 personal effects, 127 fees for legal services, employment agencies, etc, 15-16 net tourist expenditure.

${ }^{7}$ See Andersson and Guibourg (2001).

${ }^{8}$ Financial Accounts, annual figures by sector, item and counter-part sector.

${ }^{9}$ Norway has statistics on cash holdings by non-financial firms. Given the existent similarities between Sweden and Norway in the payment market, we assumed that the ratio between cash holdings by financial and non financial firms in Norway could be applied to Swedish data. For the years 2000-2004, we assumed that the same average ratio applied. 
as described in section 2.1, i.e. cash holdings by individuals for transaction purposes, safety buffers held by individuals, cash held by banks and the government and estimations of cash held by nonfinancial companies. As seen in Table 1, the cash requirement that can be explained by POStransactions and cash holdings sums up to approximately SEK 30 billion. Hence, the explained demand for cash is approximately $33-35$ percent of the total currency in circulation in the period $2000-2004$.

Table 1. Cash use in Sweden. Amounts are in SEK million and the share is in percentage of MO.

\begin{tabular}{|c|c|c|c|c|c|}
\hline & 2000 & 2001 & 2002 & 2003 & 2004 \\
\hline Value of cash payments in registered sales & 400280 & 366218 & 277101 & 301017 & 279758 \\
\hline / velocity of cash (No. of ATM withdrawals per year and person) & 44 & 45 & 43 & 44 & 45 \\
\hline$=$ Cash requirements for transactions & 9178 & 8090 & 6423 & 6883 & 6276 \\
\hline + Safety buffer & 3377 & 3392 & 3415 & 3439 & 3468 \\
\hline + cash in banks, government and companies & 16685 & 20564 & 22018 & 21044 & 21309 \\
\hline$=$ Total cash requirement & 29240 & 32045 & 31856 & 31366 & 31052 \\
\hline$/ \mathrm{MO}$ & 83274 & 87664 & 89957 & 92656 & 93897 \\
\hline$=$ Explained share & 35 & 37 & 35 & 34 & 33 \\
\hline 1 - explained share $=$ unexplained share & 65 & 63 & 65 & 66 & 67 \\
\hline unexplained share with larger velocity of cash & 68 & 66 & 67 & 68 & 69 \\
\hline
\end{tabular}

\subsection{The Unexplained Demand for Cash}

The unexplained demand for cash is the part of the currency in circulation that cannot be explained by the purposes specified in Table 1. Between 2000 and 2004, this unexplained demand has remained relatively constant at between 63 and 67 percent of the total currency in circulation (for the whole period 1990-2004, see the solid line in Figure 2). These results are robust to different estimates of the velocity of cash in POS transactions. Assuming that our figures underestimated the true velocity by as much as 20 percent, this would result in a moderate increase in the residual of 23 percentage units (see Table 1). Our estimates of both the explained and the unexplained shares of the stock of outstanding cash are consistent with estimates from Norway. According to an update of the study by Humphrey et al (2000), the unexplained share of cash in 2000 amounted to 67 percent in Norway, which is in line with the 65 per cent in Sweden in the same year. ${ }^{10}$

However, in our calculations, we have not accounted for cash used for second-hand trade and cash that has been lost or accidentally destroyed. The former increases the explained demand for cash and the latter reduces the currency in circulation. Below we refine our estimate of unexplained demand by accounting for these factors.

\footnotetext{
${ }^{10}$ Humphrey et al (2004)
} 
We estimate the second-hand market turnover to be SEK 96 billion in 2004. This includes secondhand trade on the Internet. ${ }^{11}$ However, adding this estimate only decreased the unexplained demand for cash by two percentage units, i.e. from 67 percent to 65 percent in 2004 . We do not have estimates for second-hand trade on the Internet for the previous 1-2 years, i.e. the period in which this type of trade became popular. It turns out that differences in the estimate of the value spent on the second hand-market do not have any significant effect on the result. Increasing (decreasing) the estimated turnover by 50 percent only reduces (increases) the unexplained demand with one percentage unit.

Part of the stock of cash officially in circulation is likely to have been lost or accidentally destroyed. In the 2001 Euro cash changeover process, a number of European national currencies were replaced by the Euro. On average 90 percent of the national currencies were redeemed, but the national differences were large. ${ }^{12}$ In the following, we assume this average of 10 percent not redeemed to be a fair approximation of lost and destroyed cash in Sweden. This reduces the stock of cash in circulation by 10 percent which, in turn, reduces the unexplained demand. However, accounting for second-hand trade and lost cash, the unexplained demand for cash was still 58 percent of $M 0$ in 2004 (see the dotted line in Figure 2).

Figure 2. Percentage of currency in circulation not used in recorded economic activity.

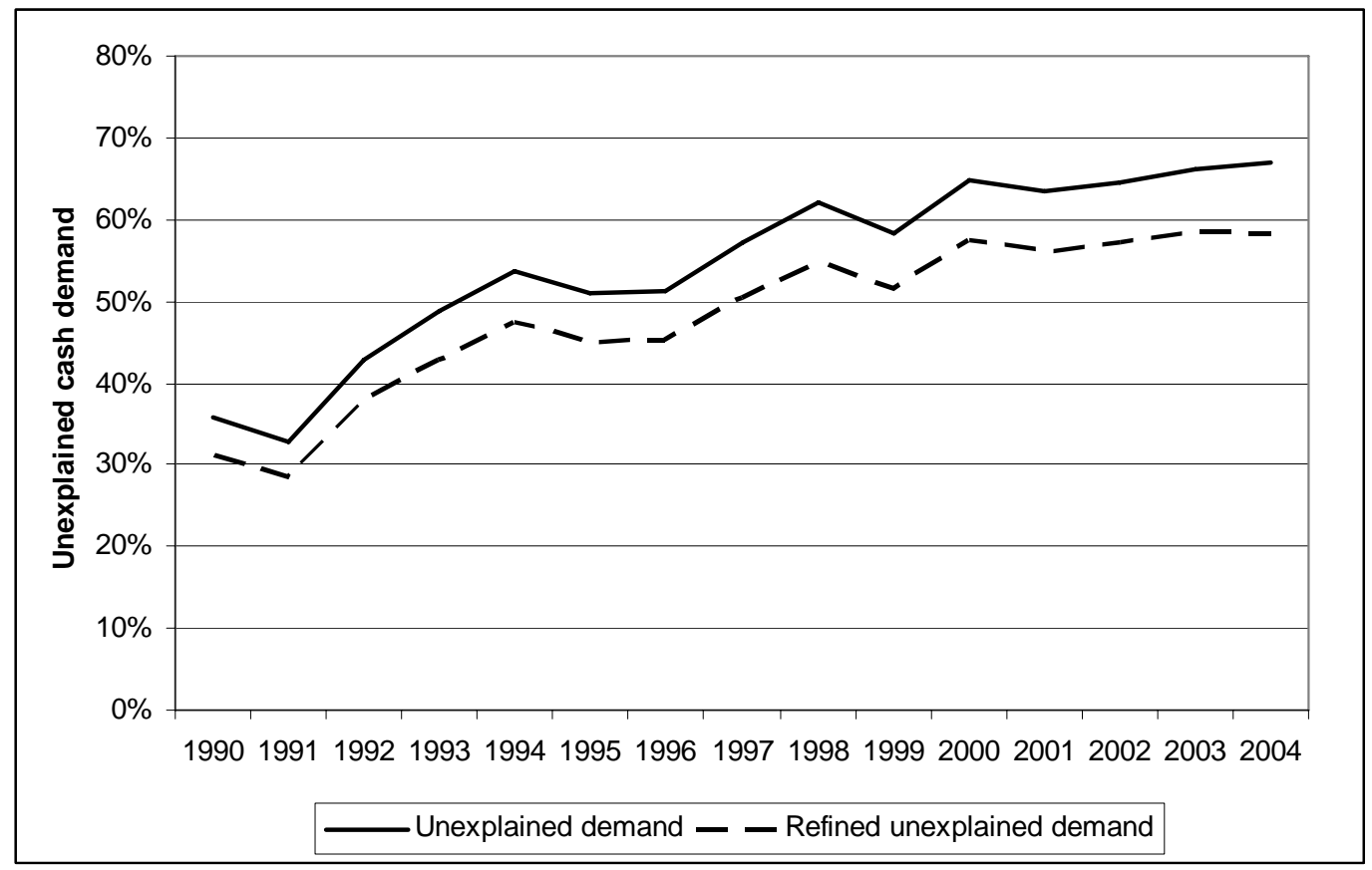

\footnotetext{
${ }^{11}$ Andersson and Guibourg (2001) estimate the value spent on the second-hand markets to be SEK 40 billion in 1999 . In 2004 , we estimate the value spent on the second-hand market over the Internet to be SEK 56 billion. This estimate is based on direct surveys of second-hand market web sites. It is likely that second-hand trade over the Internet has crowded out some of the second-hand trade previously conducted outside the Internet. However, to be certain that we do not underestimate the total second-hand market, we add the estimates of Internet based and non-Internet based second-hand trade.

${ }^{12}$ Stenkula (2003).
} 
Between 1990 and 2004, cash has come to be used relatively less as means of payment at the POS. In nominal terms, we estimate the use of cash at POS to be SEK 289 billion in 1990 and SEK 279 billion in $2004 .^{13}$ The nominal use of cash is thus almost unchanged but the velocity of cash in recorded POS transactions almost doubled from 24 to 45 during the same period which reduced the explained demand for cash in nominal terms by almost one half. The increased velocity also made the demand for cash less sensitive to changes in the use of cash, i.e. an increase in the velocity implies that a given cash POS turnover can be sustained with less cash in circulation. Including cash held by the government, financial institutions, firms and consumers, the nominal demand for cash remained almost unchanged during the period - SEK 35 billion in 1990 and SEK 31 billion in 2004. However, the amount of cash in circulation increased from SEK 55 billion to SEK 94 billion. Hence, the unexplained demand for cash increased from 31 to 58 percent of MO. Our explanation of this unexplained increase in the demand for cash is that it is used for non-registered economic activities, i.e. that it is used in the shadow economy.

\section{The Shadow Economy}

In this section, we estimate the size of the shadow economy. The underlying assumptions are that the shadow economy is cash based and that the stock of cash that we cannot explain from registered transactions and cash holdings is used for transactions in the shadow economy. However, in order to express the unexplained cash demand, which is a stock measure, as a share of GDP, which is a flow measure, we need to transform the stock of unexplained cash into a turnover in the shadow economy. We believe there to be a significant difference between cash use in recorded POS transactions and cash use in non-recorded transactions in the shadow economy, e.g. cash payments are likely to be larger in the shadow economy and there is likely to be relatively fewer transaction opportunities. For this reason, we will not use the same ATM-withdrawal based velocity measure as above. Instead, we will follow earlier studies, e.g. Schneider and Enste (2000), of the shadow economy which have approximated the velocity of cash in the shadow economy with the velocity of money (M1) in the formal economy, i.e. GDP/M1. ${ }^{14}$ Relating the estimated turnover in the shadow economy to GDP gives the relative size of the shadow economy:

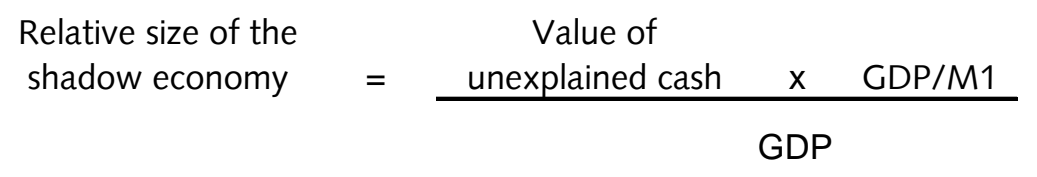

\footnotetext{
${ }^{13}$ During the same period, the estimated POS turnover increased from SEK 409 billion to SEK 752 billion.

${ }^{14} \mathrm{M} 1$ is equal to the sum of $\mathrm{MO}$ and demand deposits in monetary financial institutions and the Swedish National Debt Office by the Swedish public. Demand deposits are defined as overnight loans and deposits in transaction accounts.
} 
In the Norwegian study by Humphrey et al. (2004), the implementation of the velocity GDP/M1 to the unexplained stock of outstanding cash results in estimates of the size of the shadow economy that amounted to 7.5 percent in 2000 . These estimates are consistent with previous studies that estimated tax evasion activities in Norway to 4-6 per cent of GDP in the 1980s. These figures rose to $6.3-7.5$ per cent when estimates of the value spent on other illegal activities were added. ${ }^{15}$

Applying Equation (1) to Swedish data results in estimates of the Swedish shadow economy that are close to the Norwegian figures. On average, the size of the shadow economy between 1998 and 2004 amounted to 6.5 percent of GDP. This is broadly in line with the estimates published by the Swedish Tax Agency (2006). In Sweden, there is no data on M1 before 1998. However, the ratio GDP/M1 has been quite stable during the period 1998 - 2004. Assuming this to also having been the case for 1990 - 1997, we can compute the average value of the years for which this ratio is available and use it as an estimate of the velocity of cash in the shadow economy for the previous years. ${ }^{16}$ Using this estimate, we observe a long-term growth in the shadow economy in Sweden. Its size increased from 3.8 percent of GDP in 1990 to 6.5 percent in 2004. On average for the whole period, the size of the shadow economy amounted to 5.7 per cent. ${ }^{17}$

These results are dependent on GDP/M1 being a good approximation of the velocity of cash in the shadow sector, however. It is reasonable to believe that the relatively fewer possibilities of transacting in the shadow economy should result in a lower velocity of cash than in recorded economic activities. Assuming, for example, that the velocity of cash in the shadow economy is half of M1/GDP, the relative size of the shadow economy becomes 1.9 of GDP in 1990 and 3.2 percent in 2004. If we instead assume the velocity to be 1.5 times the GDP/M1, our estimates of the relative size of the shadow economy range between 5.7 and 9.7 per cent in the same period (see Figure 3). Despite the difficulty in finding the correct turnover ratio, our study indicates a long-term growth of the relative size of the shadow economy (Figure 3). Below we investigate if this growth can be supported by data on household income, savings and consumption.

\footnotetext{
${ }^{15}$ See Humphrey et al. (2004) and Isachsen and Strom (1985).

${ }^{16}$ One might object to the use of a constant proxy for M1/GDP in the period prior to 1998. However, M1/GDP figures for Finland and Norway are close to the Swedish figures and they show that: i) a small increase in the ratio of $0.4-0.5$ percentage units has occurred during the whole period. ii) if we adopt the same trend to the Swedish data, this means that the assumption of a constant M1/GDP ratio for the beginning of the period may have underestimated the size of the shadow economy by approximately 0.5 percentage units at the beginning of the period.

${ }^{17}$ Statistics Sweden includes a mark-up in GDP figures that accounts for the production of goods and services in the shadow economy. However, this mark-up is very low and does not affect our estimate of the relative size of the shadow economy.
} 
Figure 3. The shadow economy in Sweden between 1990 and 2004 given velocity equals GDP/M1, $0.5 \mathrm{GDP} / \mathrm{M} 1$ or $1.5 \mathrm{GDP} / \mathrm{M} 1$.

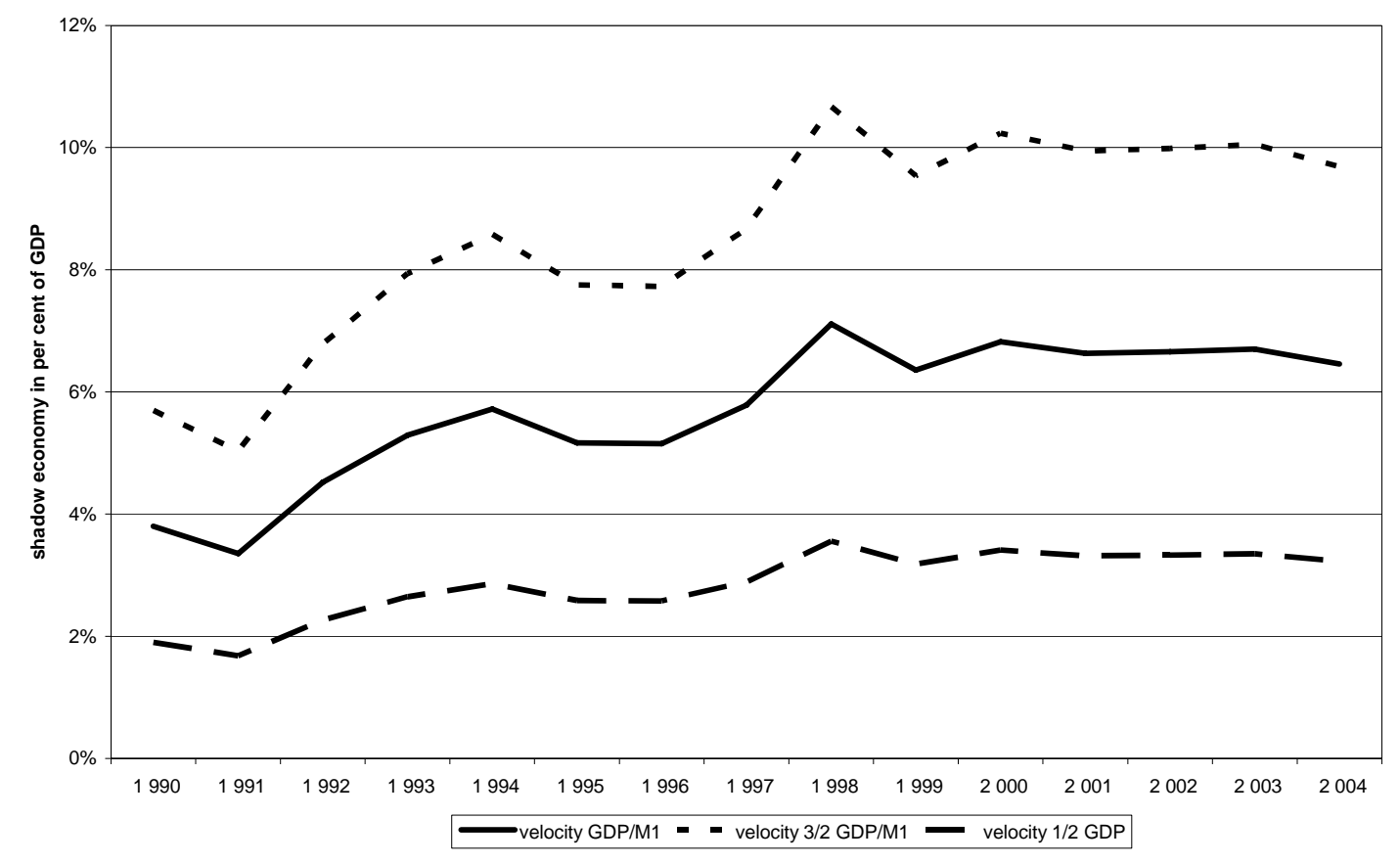

\subsection{The Household Budget Restriction Approach}

With the unexplained cash demand method, we find that the share of the currency in circulation used in unrecorded economic activities and thus also the size of the shadow economy in Sweden have increased in the period 1990 - 2004. We want to confirm this trend by using a different approach. The simple idea behind the household budget restriction approach is that household expenditures are restricted by household budgets. The budget restriction is illustrated in Equation (2) where, at any point in time, disposable income $\left(Y^{d}\right)$ equals the sum of consumption (C), investments $(\mathrm{I})^{18}$ and net savings (S), i.e. changes in the net financial position:

$$
Y_{i}^{d}=C_{i}+I_{i}+S_{i} i=\text { household } 1, \ldots, \text { household } n
$$

Suppose that, given official data, Equation (2) does not hold and the right-hand side is larger than the left-hand side. This means that disposable income underestimates the household's real income. Part of this difference may be explained by the household having an income that is not recorded. It could be labour income that has evaded taxation or revenues from criminal activities. It might also be the case that households have made use of previously accumulated unrecorded savings. On the other hand, if disposable income exceeds consumption expenditures, investments and net savings, this could be an indication that the household is purchasing goods or services in the shadow sector

\footnotetext{
${ }^{18}$ In the Swedish statistics, households' expenditures on building new houses, summer houses, rebuilding and reparations are not included in consumption figures. Instead, they are categorised as household investments.
} 
and/or that it is building up unrecorded savings, i.e. recorded net savings underestimate the household's true net savings.

Studying the residual in Equation (2) for a sample of households could be used as an alternative method for estimating the size of the shadow economy. Unfortunately, only macro data is available on these variables. At the aggregate level, what is an unrecorded purchase by one household is an unrecorded income for another and this income can be used for recorded consumption, saving or investment. Therefore, it is possible that Equation (2) holds even in the presence of non-recorded economic activities and that both the income- and the expenditure sides underestimate real income and consumption, saving and investment. However, unrecorded changes in households' net financial position in Sweden and abroad and unrecorded net flows of income to or from other countries are not automatically off-set by corresponding changes in other households' consumption or income. A residual in Equation (2) when using macro data captures the sum of these unrecorded cross-border flows and unrecorded changes in households' domestic net financial position. We argue that the residual should be monotonic in the turnover in the shadow economy, i.e. an increased turnover should not decrease the net capital outflow or unrecorded domestic savings. An increase in the residual for the period 1990-2004 should thus lend qualitative support to our finding of a growing shadow economy.

\subsection{The Data}

All data is taken from Statistics Sweden. As regards consumption data, we used the National Accounts Statistics on households' annual consumption expenditure by purpose. ${ }^{19}$ We also retrieved annual data on new investments in small houses from the National Accounts. ${ }^{20}$ The database on Households' Finances provided us with information on numbers of households by type of household and disposable income. The disposable income data includes recorded flows of income into and out of the country. ${ }^{21}$

Annual data on changes in households' net financial position, i.e. assets minus loans, was provided by the Financial Accounts. ${ }^{22}$ Because of changes in the definitions used by Statistics Sweden in 1995, our dataset starts in that year. Households' net savings according to the National Accounts should equal their net savings according to the Financial Accounts if the compilation method used could accurately capture households' financial assets and debts. However, there is a difference between the two. In order to get these two series to coincide, Statistics Sweden includes a correction post in the data on households' net savings in the Financial Accounts. This correction post is surprisingly

\footnotetext{
${ }^{19}$ Include items 01-16 in ENS 95 excluding Statistics Sweden's income additions for own homes, items $0421,0422$.

${ }^{20}$ We received the data and relevant information directly in the National Accounts, Statistics Sweden. Statistics Sweden includes investments in apartments under assets in the Financial Accounts and these are thus included in our financial savings data.

${ }^{21}$ This data was collected by the Riksbank until 2002. No data is available after that year.

${ }^{22}$ The data comprises households' currency and deposits, bonds and convertible loans, financial derivatives, loans, shares, other equities and mutual fund shares - domestic and foreign, insurance technical reserves - domestic and foreign, trade credits. The data is measured in terms of financial transactions during the year. For more details, see Statistics Sweden, Financial Accounts, Table 6 Households, transactions (SEK million).
} 
large and it has increased substantially during this period (see Table 2). We did not include the correction post in our data set since it may to some extent capture unrecorded savings in foreign bank accounts, something that we want to capture ourselves when examining our dataset. Instead, we use the data on net savings actually measured in the Financial Accounts (the second row in Table 2). The correction post may include measurement errors derived by erroneous assumptions used in the collection of data in the National and the Financial Accounts. However, there is no reason to expect these errors to increase over time.

Table 2. Households' net savings according to National Accounts (NA) and the Financial Accounts (FA), 1995-2004, SEK million.

\begin{tabular}{lrrrrrrrrrrr}
\hline & $\mathbf{1 9 9 5}$ & $\mathbf{1 9 9 6}$ & $\mathbf{1 9 9 7}$ & $\mathbf{1 9 9 8}$ & $\mathbf{1 9 9 9}$ & $\mathbf{2 0 0 0}$ & $\mathbf{2 0 0 1}$ & $\mathbf{2 0 0 2}$ & $\mathbf{2 0 0 3}$ & $\mathbf{2 0 0 4}$ \\
\hline Savings according to NA & 82496 & 60126 & 36440 & 25034 & 14411 & 25855 & 92879 & 101610 & 100278 & 91450 \\
Savings according to FA & $\mathbf{8 1 8 6 4}$ & $\mathbf{7 7 4 6 2}$ & $\mathbf{4 6 2 3 6}$ & $\mathbf{2 1 9 9 9}$ & $\mathbf{3 3 9 4 7}$ & $\mathbf{8 4 2 4}$ & $\mathbf{6 2 8 7 6}$ & $\mathbf{4 4 4 6 5}$ & $\mathbf{6 0 9 8 2}$ & $\mathbf{5 1 9 5}$ \\
NA- FA (corection post) & 632 & -17336 & -9796 & 3035 & -19536 & 17431 & 30003 & 57145 & 39296 & 86255 \\
\hline
\end{tabular}

Table 3 presents the households' disposable income, net savings, consumption and investments 1995-2004 in SEK million. In the table, R denotes the household residual, i.e. the difference between households' disposable income on the one hand and changes in the net financial position, investments and consumption expenditures on the other.

Table 3. Estimation of the residual between households' disposable income and net savings, investments and consumption.

\begin{tabular}{|c|c|c|c|c|c|c|c|c|c|c|}
\hline & 1995 & 1996 & 1997 & 1998 & 1999 & 2000 & 2001 & 2002 & 2003 & 2004 \\
\hline$\overline{Y d}$ & 791267 & 823168 & 859367 & 872686 & 933593 & 1043235 & 1057545 & 1101211 & 1124640 & 1139142 \\
\hline$S$ & 81864 & 77462 & 46236 & 21999 & 33947 & 8424 & 62876 & 44465 & 60982 & 5195 \\
\hline C & 762060 & 785565 & 826711 & 859033 & 910943 & 958758 & 990584 & 1019075 & 1054152 & 1092969 \\
\hline I & 24791 & 26484 & 27760 & 31848 & 34990 & 38427 & 41046 & 45404 & 50009 & 55883 \\
\hline$R=Y d-S-C-I$ & -77448 & -66343 & -41340 & -40195 & -46288 & 37626 & -36961 & -7733 & -40503 & -14904 \\
\hline
\end{tabular}

We see that with the exception of the year 2000, the household residual is negative which means that households' spending exceeded their disposable income during most of the period. ${ }^{23}$ Therefore, it seems like households spend previously unrecorded savings or receive unrecorded income from abroad. However, the household residual tends to decrease over time which, everything else equal, means that unrecorded outflows of capital are increasing in accordance with our expectations.

\subsection{Are the Measures Related?}

The hypothesis underlying the unexplained cash demand method is that the unexplained demand for cash is an increasing function of the value of non-recorded economic activities. Implemented on Swedish data, this method shows that the unexplained demand for cash and consequently, the

'It is a sharp decrease in savings that caused the positive residual in 2000 . This may have been caused by the crash in the stock market observed in the same year. 
shadow economy, have increased during the period 1990-2004. The idea is that the household residual $\mathrm{R}$ is an increasing function of the size of the shadow economy, i.e.

$$
R=f(S H) ; f^{\prime}>0
$$

where $\mathrm{SH}$ denotes the size of the shadow economy. This is a reasonable assumption due to net unrecorded savings and foreign workers taking home "shadow" income. We believe that the unrecorded savings in foreign bank accounts resulting from the wealth tax evasion decision should be positively correlated to the size of the shadow economy. Then, if the shadow economy grows, we should expect increasing outflows of unrecorded savings. Second, it is reasonable to believe that the aggregate income of foreign workers in the shadow economy is an increasing function of the size of the shadow economy. This should, in turn, imply a growing unrecorded export of capital as part of this income is transferred to the workers' home countries. ${ }^{24}$ Altogether, the above implies that the household residual should behave as specified in Equation (3). That is, we expect to find a positive correlation between the household residual and the unexplained demand for cash. When computing the correlation between the two, we also find a positive correlation coefficient equal to 0.65. It is statistically significant at the 5 percent level $(t=2.41)$. Thus, we find support for our hypothesis of a growing shadow economy in Sweden for the period 1995- 2004.

\section{Discussion}

Starting from the observed cash use and the overall demand for cash, we have estimated the size of the shadow economy in Sweden. Through the unexplained cash demand method, we have shown that the size of the shadow economy has increased between 1990 and 2004. Using a different data set and observing the discrepancies between households' disposable income and their use of this income, we found supporting evidence for this increase. Our findings are in line with a recent study by the Swedish Tax Agency. ${ }^{25}$ The unexplained-cash method relies on the assumption of the velocity of cash in the shadow economy. However, little is know about this velocity and further research on this topic would be valuable as it would provide better estimates of the size of the shadow economy.

No obvious policy prescription follows directly from our study. A policy maker who wants to reduce the size of the shadow economy must have knowledge of the driving forces behind the shadow economy. Previous research has shed some light on the causes. Large shadow economies seem to be related to high tax regimes. According to the Swedish Tax Agency's (2006), tax evasion is more likely to occur in the work-intensive service producing sector, particularly among self-employed, than in capital intensive sectors of the economy. In addition to this, we expect the degree of regulation of the various markets to play an important role in the size of the shadow economy, e.g.

\footnotetext{
${ }^{24}$ Other unregistered net flows related to the households' budget constraint are assumed to be constant. This assumption is consistent with the relatively stable recorded in- and outflow of income and capital during the period 1995 and 2002.

${ }_{25}$ Swedish Tax Agency (2006).
} 
complicated rules that make formal economic activity difficult may give incentives to make the transaction informal. Moreover, a growing shadow economy may not only depend on increasing taxation and regulation, but on the erosion of social norms. It may simply be the case that buying and selling in the shadow economy has become more acceptable in the population as a whole. ${ }^{26}$ In this light, our study acquires a greater relevance for policy makers: an increasing share of total GDP of the shadow economy - such as reported in our study - is an indicator to policy makers that if the trend continues, the legitimacy of the welfare state may eventually be threatened by the change in values. Finally, the cash-based transactions in the shadow economy give rise to seigniorage income for the central bank. In this sense, this seigniorage may be viewed as an, albeit low, implicit tax on the shadow economy. ${ }^{27}$ All these factors must be considered in future policy discussions.

\footnotetext{
${ }^{26}$ The impact of social norms in tax evasion has been confirmed in a number of studies. Wenzel (2005a) shows, among other things, that perceived social norms affect personally held tax ethics for individuals strongly identifying themselves with the group in question. In Wenzel (2005b), he gives experimental evidence of the importance of taxpayers' estimation of other people's acceptance of tax evasion. Alm et. al. (1995) also give experimental evidence of the impact of social attitudes toward tax evasion. These social attitudes may also affect the lower deterrent effect of the authorities' tax enforcement; see Chan and Lai (2004). The role of social norms for tax morale is also shown in country comparisons between the U.S. and 14 European countries; see Alm and Torgler (2006).

${ }^{27}$ We estimate this implicit tax to be approximately SEK $1 \mathrm{bn}$ in 2004. This calculation is based on our estimate of the stock of unexplained cash being equal to 58 percent of $M O$ in 2004. We then use the average repo interest rate of 1.9 percent to calculate the seigniorage on the unexplained part of $\mathrm{MO}$.
} 


\section{References}

Alm, J., I. Sanchez and A. de-Juan (2005), Economic and Noneconomic Factors in Tax Compliance. Kyklos 48(1):3-18.

Alm, J. and B. Torgler (2006), Culture Differences and Tax Morale in the United States and in Europe. Journal of Economic Psychology 27(2): 224-46.

Andersson, M. and G. Guibourg (2001). The Use of Cash in the Swedish Economy. Sveriges Riksbank Economic Review 2001(4): 28-37.

Chang, J. and C. Lai (2004), Collaborative Tax Evasion and Social Norms: Why Deterrence Does Not Work. Oxford Economic Papers 56(2): 344-68.

Engström, P., and B. Holmlund (2006). Tax Evasion and Self-Employment in a High-Tax Country: Evidence from Sweden. Working Paper 2006:12, Department of Economics, Uppsala University.

Fleming, M., J. Roman and G. Farrell (2000). The Shadow Economy. Journal of International Affairs 53(2): 387-412.

Houston, J., (1990). The Policy Implications of the Underground Economy. Journal of Economic and Business 42(1): 27-37.

Humphrey, D., A. Kaloudis and G. Öwre (2000). Forecasting Cash Use in Legal and Illegal Activities. Norges Bank Working Papers, 2000/14.

Humphrey, D., A. Kaloudis and G. Öwre (2004). The future of cash: falling legal use and implications for government policy, Journal of International Financial Markets, Institutions and Money 14 (3): 221-233.

Isachsen, A. and S. Strom (1985). The size and growth of the hidden economy in Norway. Review of Income and Wealth 31(1): 21- 38.

Johnson, S., D. Kaufmann and P. Zoido-Lobatón (1998a). Regulatory Discretion and the Unofficial Economy. The American Economic Review 88(2): 387-392

Johnson, S., D. Kaufmann and P. Zoido-Lobatón (1998b). Corruption, Public Finances and the Unofficial Economy. The World Bank Policy Research Working Paper Series, Working Paper 2169.

Karlinger, L. (2006). The Underground Economy in the Late 1990s: Evading Taxes, or Evading Competition?. Mimeo.

Nyberg, L. and G. Guibourg (2003). Card Payments in Sweden. Sveriges Riksbank Economic Review 2003(2): 29-40. 
Schneider, F. and D. Enste (2000). Shadow economies: size, causes, and consequences. Journal of Economic Literature 38(1): 77-114.

Schneider, F. (1994). Can the Shadow Economy be reduced through Major Tax Reforms? An Empirical Investigation for Austria. Public Finance/Finances Publiques, 49(0), supplement: 137-152.

Schneider, F. (2005). Shadow economies around the world: what do we really know? European Journal of Political Economy 21(3): 598-642.

Stenkula, M., (2003). The Euro Cash Changeover Process. Ph.D thesis, Department of Economics, Lund University.

Swedish Tax Agency (2006), "Svartköp och svartjobb i Sverige", Rapport 2006:4

Wenzel, M. (2005a), Motivation or Rationalisation? Causal Relations between Ethics, Norms and Tax Compliance. Journal of Economic Psychology 26(4): 491-508.

Wenzel, M. (2005b), Misperceptions of Social Norms about Tax Compliance: From Theory to Intervention. Journal of Economic Psychology 26(6): 862-83. 


\section{Earlier Working Papers:}

For a complete list of Working Papers published by Sveriges Riksbank, see www.riksbank.se

Evaluating Implied RNDs by some New Confidence Interval Estimation Techniques

by Magnus Andersson and Magnus Lomakka....

Taylor Rules and the Predictability of Interest Rates

by Paul Söderlind, Ulf Söderström and Anders Vredin ......................................................... 2003:147

Inflation, Markups and Monetary Policy

by Magnus Jonsson and Stefan Palmqvist.....

Financial Cycles and Bankruptcies in the Nordic Countries by Jan Hansen........................................ 2003:149

Bayes Estimators of the Cointegration Space by Mattias Villani .................................................. 2003:150

Business Survey Data: Do They Help in Forecasting the Macro Economy?

by Jesper Hansson, Per Jansson and Mårten Löf

The Equilibrium Rate of Unemployment and the Real Exchange Rate:

An Unobserved Components System Approach by Hans Lindblad and Peter Sellin ........................ 2003:152

Monetary Policy Shocks and Business Cycle Fluctuations in a

Small Open Economy: Sweden 1986-2002 by Jesper Lindé

Bank Lending Policy, Credit Scoring and the Survival of Loans by Kasper Roszbach .......................... 2003:154

Internal Ratings Systems, Implied Credit Risk and the Consistency of Banks' Risk

Classification Policies by Tor Jacobson, Jesper Lindé and Kasper Roszbach .................................. 2003:155

Monetary Policy Analysis in a Small Open Economy using Bayesian Cointegrated

Structural VARs by Mattias Villani and Anders Warne

Indicator Accuracy and Monetary Policy: Is Ignorance Bliss? by Kristoffer P. Nimark ........................ 2003:157

Intersectoral Wage Linkages in Sweden by Kent Friberg .......................................................... 2003:158

Do Higher Wages Cause Inflation? by Magnus Jonsson and Stefan Palmqvist ............................. 2004:159

Why Are Long Rates Sensitive to Monetary Policy by Tore Ellingsen and Ulf Söderström .................. 2004:160

The Effects of Permanent Technology Shocks on Labor Productivity

and Hours in the RBC model by Jesper Lindé........................................................................ 2004:161

Credit Risk versus Capital Requirements under Basel II: Are SME Loans and Retail

Credit Really Different? by Tor Jacobson, Jesper Lindé and Kasper Roszbach

Exchange Rate Puzzles: A Tale of Switching Attractors

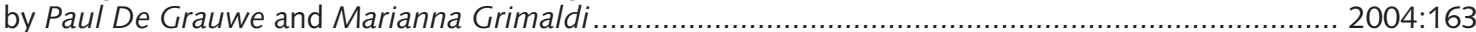

Bubbles and Crashes in a Behavioural Finance Model

by Paul De Grauwe and Marianna Grimaldi.

Multiple-Bank Lending: Diversification and Free-Riding in Monitoring

by Elena Carletti, Vittoria Cerasi and Sonja Daltung.............................................................. 2004:165

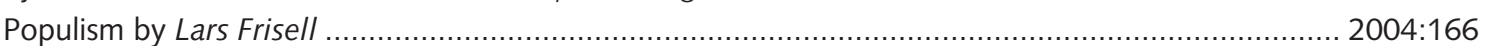

Monetary Policy in an Estimated Open-Economy Model with Imperfect Pass-Through

by Jesper Lindé, Marianne Nessén and Ulf Söderström

Is Firm Interdependence within Industries Important for Portfolio Credit Risk?

by Kenneth Carling, Lars Rönnegård and Kasper Roszbach

$2004: 168$

How Useful are Simple Rules for Monetary Policy? The Swedish Experience

by Claes Berg, Per Jansson and Anders Vredin

The Welfare Cost of Imperfect Competition and Distortionary Taxation

by Magnus Jonsson

A Bayesian Approach to Modelling Graphical Vector Autoregressions

by Jukka Corander and Mattias Villani

Do Prices Reflect Costs? A study of the price- and cost structure of retail payment

services in the Swedish banking sector 2002 by Gabriela Guibourg and Biörn Segendorf

Excess Sensitivity and Volatility of Long Interest Rates: The Role of Limited

Information in Bond Markets by Meredith Beechey.

State Dependent Pricing and Exchange Rate Pass-Through

by Martin Flodén and Fredrik Wilander.

The Multivariate Split Normal Distribution and Asymmetric Principal

Components Analysis by Mattias Villani and Rolf Larsson

Firm-Specific Capital, Nominal Rigidities and the Business Cycle

by David Altig, Lawrence Christiano, Martin Eichenbaum and Jesper Lindé

Estimation of an Adaptive Stock Market Model with Heterogeneous Agents by Henrik Amilon ........ 2005:177

Some Further Evidence on Interest-Rate Smoothing: The Role of Measurement

Errors in the Output Gap by Mikael Apel and Per Jansson...... 
Bayesian Estimation of an Open Economy DSGE Model with Incomplete Pass-Through by Malin Adolfson, Stefan Laséen, Jesper Lindé and Mattias Villani......

Are Constant Interest Rate Forecasts Modest Interventions? Evidence from

an Estimated Open Economy DSGE Model of the Euro Area by Malin Adolfson,

Stefan Laséen, Jesper Lindé and Mattias Villani

$2005: 180$

Inference in Vector Autoregressive Models with an Informative

Prior on the Steady State by Mattias Villani

Bank Mergers, Competition and Liquidity by Elena Carletti, Philipp Hartmann

and Giancarlo Spagnolo

Testing Near-Rationality using Detailed Survey Data

by Michael F. Bryan and Stefan Palmqvist.

Exploring Interactions between Real Activity and the Financial Stance

by Tor Jacobson, Jesper Lindé and Kasper Roszbach 2005:184

Two-Sided Network Effects, Bank Interchange Fees,

and the Allocation of Fixed Costs by Mats A. Bergman

Trade Deficits in the Baltic States: How Long Will the Party Last?

by Rudolfs Bems and Kristian Jönsson..... 2005:186

Real Exchange Rate and Consumption Fluctuations follwing Trade Liberalization

by Kristian Jönsson

Modern Forecasting Models in Action: Improving Macroeconomic Analyses at Central Banks

by Malin Adolfson, Michael K. Andersson, Jesper Lindé, Mattias Villani and Anders Vredin .......... 2005:188

Bayesian Inference of General Linear Restrictions on the Cointegration Space by Mattias Villani ..... 2005:189

Forecasting Performance of an Open Economy Dynamic Stochastic General Equilibrium Model

by Malin Adolfson, Stefan Laséen, Jesper Lindé and Mattias Villani....

2005:190

Forecast Combination and Model Averaging using Predictive Measures

by Jana Eklund and Sune Karlsson

Swedish Intervention and the Krona Float, 1993-2002

by Owen F. Humpage and Javiera Ragnartz

A Simultaneous Model of the Swedish Krona, the US Dollar and the Euro

by Hans Lindblad and Peter Sellin....

Testing Theories of Job Creation: Does Supply Create Its Own Demand?

by Mikael Carlsson, Stefan Eriksson and Nils Gottfries.

2006:194

Down or Out: Assessing The Welfare Costs of Household Investment Mistakes

by Laurent E. Calvet, John Y. Campbell and Paolo Sodini 2006:195

Efficient Bayesian Inference for Multiple Change-Point and Mixture Innovation Models

by Paolo Giordani and Robert Kohn .... 2006:196

Derivation and Estimation of a New Keynesian Phillips Curve in a Small Open Economy

by Karolina Holmberg....

Technology Shocks and the Labour-Input Response: Evidence from Firm-Level Data

by Mikael Carlsson and Jon Smedsaas.... $2006: 198$

Monetary Policy and Staggered Wage Bargaining when Prices are Sticky

by Mikael Carlsson and Andreas Westermark....

The Swedish External Position and the Krona by Philip R. Lane 2006:200

Price Setting Transactions and the Role of Denominating Currency in FX Markets

by Richard Friberg and Fredrik Wilander

The geography of asset holdings: Evidence from Sweden

by Nicolas Coeurdacier and Philippe Martin

2007:202

Evaluating An Estimated New Keynesian Small Open Economy Model

by Malin Adolfson, Stefan Laséen, Jesper Lindé and Mattias Villani 
